\title{
Spatial and Temporal Differences in Surface Albedo over Different Underlying Surfaces in the Badain Jaran Desert, China
}

\author{
Peng $\mathrm{He}^{1}$, Fan Yang ${ }^{2 *}$, Lishuai $\mathrm{Xu}^{1}$, Wenbo $\mathrm{Zhu}^{1}$, Xinqian $\mathrm{Zheng}^{3}$ \\ ${ }^{1}$ College of Resources and Environment, Shanxi Agricultural University, Taigu, Shanxi, China \\ ${ }^{2}$ Taklimakan Desert Meteorology Field Experiment Station of CMA, Institute of Desert Meteorology, \\ China Meteorological Administration, Urumqi, China \\ ${ }^{3}$ Xinjiang Agro-Meteorological Observatory, Urumqi 830002, China
}

Received: 5 November 2020

Accepted: 25 January 2021

\begin{abstract}
To study the change mechanism and influencing factors of surface albedo over different underlying surfaces in the Badain Jaran Desert, surface albedo derived from the Operational Land Imager (OLI) was assimilated into black-sky short-wave albedo (BSA) with four-dimensional variational (4DVAR), to retrieve high accuracy surface albedo data. The results indicated that the average relative error decreased by $12.271 \%$ when surface albedo based on OLI were assimilated into BSA with 4DVAR, and assimilated value could accurately describe the spatial and temporal distribution of surface albedo. The lag effect in the response of vegetation to precipitation was evident over the semi-fixed and fixed dunes. The surface albedo over the semi-fixed and fixed dunes was lower than that over the shifting and semi-shifting dunes owing to the high surface roughness that increases the reflection of solar radiation. The separation of surface albedo over semi-shifting, semi-fixed, and fixed dunes with patchy distribution were higher than that over shifting dunes owing to the large and continuous distribution, while landscape dominance demonstrated the opposite trend. The difference in monthly perimeter area fractal dimension of surface albedo over shifting dunes was significant owing to the organic matter and sand content while the monthly landscape pattern of surface albedo over fixed dunes was stable.
\end{abstract}

Keywords: Badain Jaran Desert, surface albedo, 4DVAR, underlying surfaces, landscape metrics

\section{Introduction}

Surface albedo is an important parameter to simulate land and climate processes $[1,2]$. Small changes in

*e-mail: yangfan309@yeah.net surface albedo can influence the regional energy balance and water-heat exchange, and can also affect climate change, especially in arid and semi-arid areas. When the surface albedo increases, the net radiation and convergence movement decreases. An increase in surface albedo leads to less cloud and rain and can lead to persistent drought and expansion of desertification in arid and semi-arid areas, which poses a risk to 
the ecology in arid and semi-arid areas [3]. Desert ecosystem has gradually attracted wide attention, due to the characteristics of arid climate, special sandy underlying surface, extremely low vegetation cover, frequent dust weather, potential carbon sequestration capacity and fragile ecological environment $[4,5]$. Compared with other ecosystems, desert has a relatively high surface albedo, which is of great significance to the formation of desert ecosystem [6]. The Badain Jaran Desert is located in the center of the Alxa Plateau, at the southeastern end of the East Asian monsoon system $[7,8]$. The Badain Jaran Desert is a tropical, subtropical desert or coastal desert controlled by subtropical high or cold ocean currents [9]. The land-atmosphere exchange in the Badain Jaran Desert has a significant impact on extreme weather events in China and Asia, and can affect global climate and regional ecology [10]. In the simulation of climate and land processes, parameterized schemes are still widely used to obtain surface albedo, which results in poor inversion accuracy of regional scale surface albedo [11]. Moreover, ignoring spatial and temporal differences in surface albedo over different underlying surfaces also affects the simulation of climate and land process $[12,13]$. Thus, obtaining high accuracy surface albedo data and analyzing the spatial and temporal differences in surface albedo over different underlying surfaces are essential for studying the land-atmosphere exchange and improving the simulation accuracy of climate and land processes in the Badain Jaran Desert under global warming.

In recent years, different methods have been used to study the spatial and temporal characteristics of surface albedo in deserts. The spatial and temporal relationships of Normalized Difference Vegetation Index (NDVI), Roughness Index (RI), and Arid Soil Surface Index (ASSI) were used to determine the seasonal dynamics of dust emissions and regional features of desert regions of East Asia [14]. In the Mu Us Desert, the long term change in direction and magnitude of surface albedo and NDVI over various spatial scales was used to monitor the spatial extent of the desert [15]. In the Badain Jaran Desert, the spatial and temporal characteristics of surface albedo were used as indicators of the change process to inform environmental management [16]. Meanwhile, there were many kinds of surface albedo products for simulating land surface processes, including Advanced Very High Resolution Radiometer (AVHRR) [17], Moderate-resolution Imaging Spectroradiometer (MODIS) based on accumulation of angular samples of Physically-based or semi-empirical algorithms [18], and Multi-angle Imaging Spectroradiometer (MISR) [19]. However, there is the potential for albedo data to be used in applications that require data at finer spatial resolutions. But it is difficult to apply such physicallybased or semi-empirical algorithms due to insufficient angular samples from one sensor within a short period for capturing surface anisotropy caused by the reduced revisit frequency [20]. To solve the problem, Shuai et al. [21] took the advantage of surface bidirectional reflectance distribution function (BRDF) information derived from MODIS albedo product to convert Landsat surface reflectance to albedo. He et al. [22] proposed a unified algorithm of incorporating Landsat spectral response functions and a database of BRDF into radiative transfer simulations to estimate surface albedo directly from the Landsat top-of-atmospheric reflectance data obtained by MSS, TM, ETM+, and OLI with few ancillary inputs. It is still difficult to find data with both high spatial and temporal resolution to analyze the spatial-temporal variation of surface albedo. One way to solve the problem is data assimilation, which has been developed and applied in meteorology and oceanography [23]. It has the capability of combining the advantages of the high temporal resolution data and high spatial resolution data. It has been used to research of NDVI [24], Leaf Area Index (LAI) [25] and soil moisture [26] with achieving preferable results.

In this study, surface albedo derived from the Operational Land Imager (OLI) was assimilated into black-sky short-wave albedo (BSA) with fourdimensional variation (4DVAR). Furthermore, skewness and landscape metrics can be used to analyse the spatial and temporal differences in surface albedo over different underlying surfaces. Thus, the main purposes of this study are (1) to obtain high accuracy surface albedo data and (2) to clarify the drivers of spatial and temporal differences in surface albedo over different underlying surfaces.

\section{Material and Methods}

\section{Study Area}

The Badain Jaran Desert is located east of Gurinai Lake, to the west of the Zongnai Mountains, north of the Beida Mountains, Heli Mountains and Yabulai Mountains, and south of Guaizi Lake (Fig. 1). The total area of the desert is $5.2 \times 10^{4} \mathrm{~km}^{2}$ and is the secondlargest shifting desert in China. The $88.51 \%$ of the underlying surface of the desert is shifting dunes, then semi-shifting dunes account for $10.28 \%$, semi-fixed and fixed dunes account for $0.84 \%$ and $0.35 \%$, respectively. The desert terrain is the highest in the southeast, lower in the northwest, and reaches the lowest point in the north. The dunes in the southeast are tall and dense. The western desert is flat and lies adjacent to the Heihe River. The Badain Jaran Desert has a temperate continental climate that is windy and dry in spring and autumn, cold in winter, and hot and rainy in summer. The direction of the wind is predominantly northwest with an average annual wind speed of $4 \mathrm{~m} / \mathrm{s}$ [27]. The Badain Jaran Desert has a high incidence of sandstorms.

\section{BSA Reconstruction Based on Time Series}

MCD43A3 (spatial resolution $500 \mathrm{~m}$ ) is formatted in HDF-EOS with a Sinusoidal projection (SIN) 


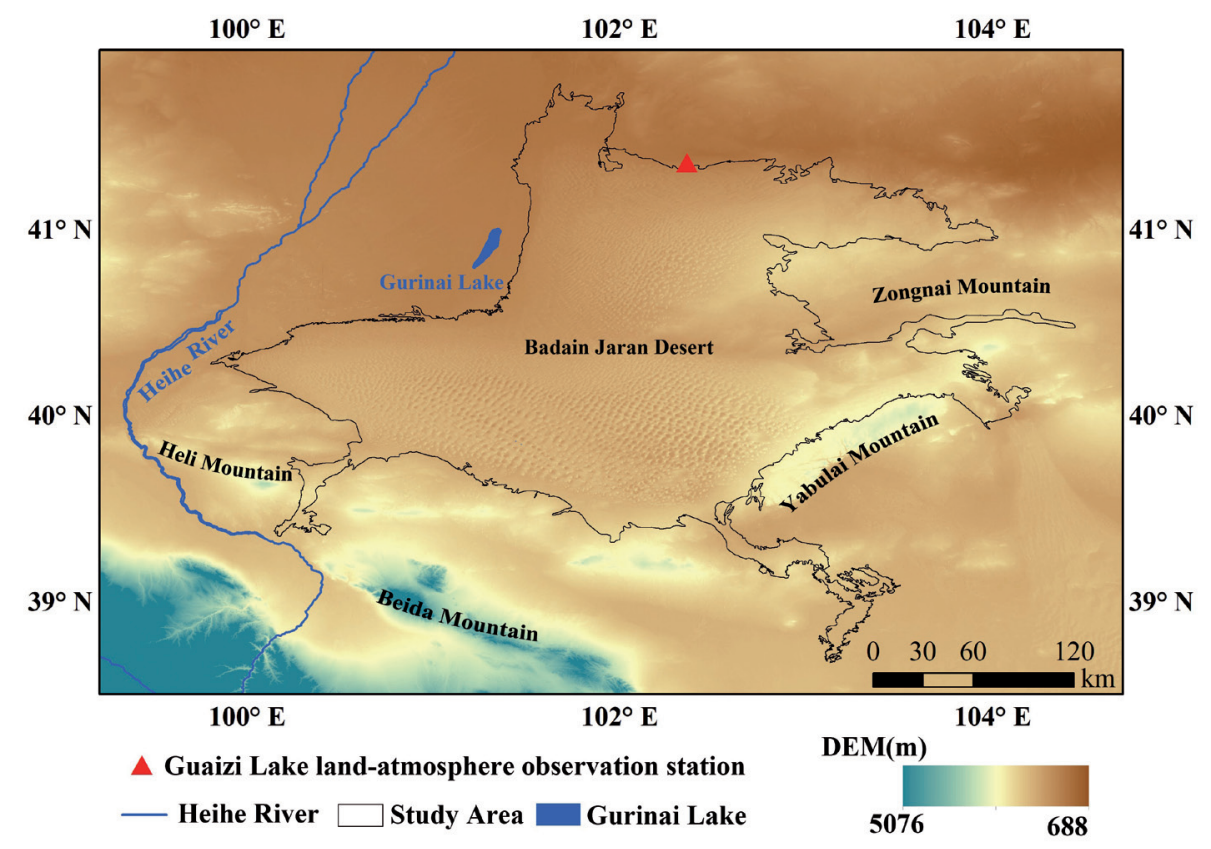

Fig. 1. Terrain of Badain Jaran Desert.

(https://ladsweb.modaps.eosdis.nasa.gov). The Badain Jaran Desert can be covered with H25V04, H25V05, and $\mathrm{H} 26 \mathrm{~V} 05$, which represent the projection numbers of MCD43A3. In this paper, we synthesized the surface albedo data by day of MCD43A3 from 2014 to 2018 and made a projection conversion. The time series of BSA chosen from MCD43A3 was reconstructed by harmonic analysis [28, 29].

\section{Surface Albedo Derived from the OLI}

A total of 64 OLI images with cloud cover less than $10 \%$ were downloaded from geospatial data clouds for the period 2014 to 2017 (http://www.gscloud.cn). The satellite orbit number and scan time were shown in Table 1. The OLI data calculated by atmospheric correction was converted to surface shortwave broadband albedo using an empirical model (Equation 1) $[30,31]$. Due to poor observation conditions, wind speed, and measured surface albedo obtained at the Guaizi Lake, the land-atmosphere observation data was only relatively complete in 2016, but lost in 2014, 2015, and 2017.

Albedo $^{\text {obs }}=0.356 \times \alpha_{2}+0.13 \times \alpha_{4}+0.373 \times \alpha_{5}+0.085 \times \alpha_{6}+0.072 \times \alpha_{7}-0.0018$

...where, Albedo ${ }_{i}^{\text {obs }}$ is the shortwave broadband surface albedo, and $a_{2}, a_{4}, a_{5}, a_{6}$, and $a_{7}$ are the blue, red, nearred, and two medium-red bands of OLI, respectively. Albedo ${ }_{i}^{o b s}$ were filtered using Savitzky-Golay to match the time scale of BSA [26].

Table 1. OLI images obtained from orbits 132/031 and 133/031.

\begin{tabular}{|c|c|c|c|c|c|c|c|c|}
\hline Path number & \multicolumn{8}{|c|}{ Scan time } \\
\hline \multirow{4}{*}{$132-031$} & 2014-07-01 & 2014-07-17 & 2014-08-18 & & & & & \\
\hline & $\begin{array}{l}2015-06-18 \\
2015-11-09\end{array}$ & $\begin{array}{l}2015-07-20 \\
2015-12-11\end{array}$ & $\begin{array}{l}2015-08-05 \\
2015-12-27\end{array}$ & $2015-08-21$ & 2015-09-06 & $2015-09-22$ & 2015-10-08 & $2015-10-24$ \\
\hline & $\begin{array}{l}2016-01-12 \\
2016-07-22\end{array}$ & $\begin{array}{l}2016-01-28 \\
2016-08-07\end{array}$ & $\begin{array}{l}2016-02-13 \\
2016-08-23\end{array}$ & $\begin{array}{l}2016-02-29 \\
2016-09-08\end{array}$ & $\begin{array}{l}2016-04-01 \\
2016-09-24\end{array}$ & $\begin{array}{l}2016-04-17 \\
2016-10-10\end{array}$ & $\begin{array}{l}2016-05-03 \\
2016-11-27\end{array}$ & $\begin{array}{l}2016-06-20 \\
2016-12-13\end{array}$ \\
\hline & $2017-04-20$ & 2017-05-06 & $2017-05-22$ & $2017-06-07$ & 2017-07-09 & $2017-08-10$ & & \\
\hline \multirow{4}{*}{ 133-031 } & $2014-06-22$ & 2014-07-08 & 2014-07-24 & 2014-08-09 & $2014-08-25$ & & & \\
\hline & $2015-06-25$ & $2015-08-28$ & $2015-09-13$ & $2015-09-29$ & 2015-10-15 & $2015-10-31$ & $2015-11-16$ & 2015-12-02 \\
\hline & $\begin{array}{l}2016-02-20 \\
2016-09-15\end{array}$ & $\begin{array}{l}2016-04-08 \\
2016-10-01\end{array}$ & $\begin{array}{l}2016-04-24 \\
2016-10-17\end{array}$ & $\begin{array}{l}2016-05-26 \\
2016-11-02\end{array}$ & 2016-06-11 & $2016-07-13$ & 2016-07-29 & 2016-08-30 \\
\hline & 2017-04-11 & $2017-04-27$ & $2017-06-30$ & & & & & \\
\hline
\end{tabular}




\section{DVAR Algorithm}

The main objective of the 4DVAR algorithm is to fully utilize the dynamic data and external observation data of the model to adjust the initial field and parameters, to simulate the observation information, and to obtain the optimal initial state of the pattern. Its essence is to transform the assimilation into an optimal solution which is dynamically coordinated and computationally effective. The optimal solution is related to the cost function based on the difference between the model solution and the observation information [32, 33]. The surface albedo derived from the OLI was assimilated into BSA using the 4DVAR. The objective function of 4 DVAR can be defined as:

$$
\begin{gathered}
J\left(\text { Albedo }_{0}\right)=1 / 2\left[\text { Albedo }_{0}-\text { Albedo }_{0}{ }^{b}\right]^{T} B^{-1}\left[\text { Albedo }_{0}-\text { Albedo }_{0}{ }^{b}\right]+ \\
1 / 2 \sum_{i=0}^{n}\left[\text { Albedo }_{i}{ }^{b}-\text { Albedo }_{i}{ }^{\text {obs }}\right]^{T} O^{-1}\left[\text { Albedo }_{i}{ }^{b}-\text { Albedo }_{i}{ }^{\text {obs }}\right]
\end{gathered}
$$

...where, Albedo $o_{0}$ is initial state variable of the assimilation; Albedo ${ }_{0}{ }^{b}$ is the background value of Albedo at an initial time, that is BSA at initial time; Albedo ${ }_{i}^{b}$ and Albedo $_{i}^{\text {obs }}$ are BSA and surface albedo derived from the OLI at time $i ; B$ and $O$ are the covariance matrix of background errors and the covariance matrix of observation errors; $n$ is assimilation days. The calculation process is as follows: the assimilation days is set to 10 . Albedo $o_{0}$ is the assimilated value when $J\left(\right.$ Albedo $\left._{0}\right)$ is the minimum. The process is repeated until all assimilated values are calculated.

\section{Landscape Metrics}

Landscape metrics are important indicators of the landscape pattern. Landscape metrics highlight landscape pattern information, reflect the structural and spatial characteristics, and provide a scientific measurement of landscape structure [34, 35]. Table 2 showed the landscape metrics that were selected to describe the spatial change in surface albedo, based on the purpose of this study and the landscape pattern characteristics of the study area. The monthly surface albedo landscape metrics of different underlying

Table 2. Landscape metrics.

\begin{tabular}{|c|c|c|}
\hline Landscape metrics & Units & Range \\
\hline Perimeter area fractal dimension (PAFRAC) & $/$ & {$[1,2]$} \\
\hline COHESION & $\%$ & $(0,100]$ \\
\hline DIVISION & $/$ & {$[0,1)$} \\
\hline SPLIT & $/$ & $>=1$ \\
\hline Shannon diversity index (SHDI) & $/$ & {$[0,1]$} \\
\hline Simpson diversity index (SIDI) & $/$ & {$[0,1]$} \\
\hline
\end{tabular}

surfaces were calculated using Fragstats4.2 to determine spatial and temporal differences in surface albedo over different underlying surfaces in the Badain Jaran Desert.

\section{Results and Discussion}

\section{Assimilation of Surface Albedo}

In contrast to the measured values from the Guaizi Lake land-atmosphere observation station, the BSA responded well to significant changes in surface albedo over a short time (Fig. 2) but did not reflect smaller changes. For instance, BSA responded better on Jun 30 and Jul 12, 2015, than on the previous days, and the measured value increased by $26.012 \%$ and $13.311 \%$ respectively. However, the BSA decreased from Jan 22 to Jan 23, 2016, when the measured value increased slowly. This means that BSA did not respond well to changes in the measured value at time nodes with a small change range from 2014 to 2017. The assimilated value could adjust BSA to the changing trend of the measured value. Moreover, the assimilated value could address the shortcomings where BSA was lower and surface albedo derived from the OLI was higher than the measured value. Table 3 showed the monthly relative errors between the assimilated value and the measured value, and between BSA and the measured value, from 2014 to 2017. The average relative error between the assimilated value and the measured value was $12.271 \%$ lower than that between BSA and the measured value. In addition, the average relative errors between BSA and the measured value were more than $20 \%$ in January, November, and December, and less than $15 \%$ in the other months. The average relative errors between the assimilated value and the measured value were $4.119 \%, 1.736 \%$, and $1.009 \%$ in January, November, and December, respectively, and less than $5 \%$ in the other months. Thus, the accuracy of the assimilated value was higher than BSA. Linear regression analysis (Fig. 3) between BSA and the assimilated value showed that BSA was positively correlated with the assimilated value, and the correlation reached a very significant level $(\mathrm{p}<0.01)$, which indicated that the assimilated value could express well the information of BSA.

Given that the acquisition time is not at noon, the solar altitude angle is small, and there is cloud cover, the surface albedo derived from the OLI is higher than the measured value $[22,36]$. According to the distance to the observated day, BSA was calculated by the waighted summation of the observated data during the 8 days before and after the observated date. As a result, the BSA cannot respond to small changes in the measured value over a relatively short period of time. The ratio of upper and lower shortwave radiation flux is used to calculate the measured value, which is applicable at a spatial scale of several meters to tens of meters. Thus, errors may occur between BSA with a spatial resolution 


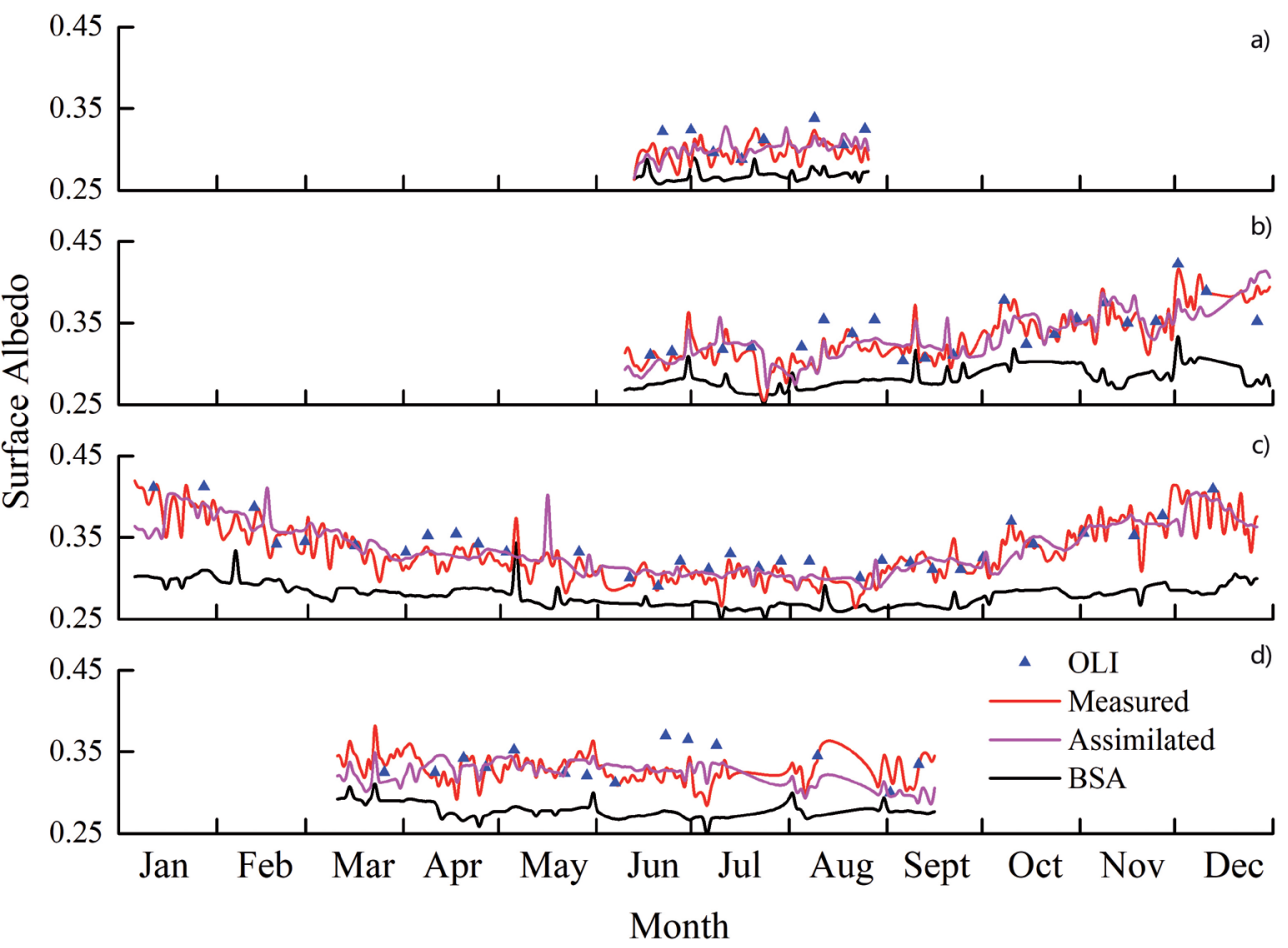

Fig. 2. Surface albedo derived from the OLI, Measured, Assimilated, and BSA at the Guaizi Lake land-atmosphere observation station, a-d represent the years from 2014-2017, respectively.

of $500 \mathrm{~m}$ and the measured value. In the Badain Jaran Desert from 2014 to 2017, the highest proportion of the full inversion is $75.491 \%$ in summer, followed by spring and autumn, and the lowest is $22.885 \%$ in winter (Fig. 7). There is snow cover in the high-elevation areas in winter, which leads to a significant spatial difference in surface albedo. The snow albedo with mixed pixels causes large relative errors between BSA and the measured value in January, November, and December [37]. This indicates that, in these areas, BSA in winter does not meet the accuracy requirements for climate and land surface processes. By combining the spatial resolution of surface albedo derived from the OLI and the temporal resolution of BSA, the assimilated value

Table 3. RE between measured value and assimilated value, BSA (\%).

\begin{tabular}{|c|c|c|c|c|c|c|c|c|}
\hline Years & \multicolumn{2}{|c|}{2014} & \multicolumn{2}{c|}{2015} & \multicolumn{2}{c|}{2016} & \multicolumn{2}{c|}{2017} \\
\hline & AV-MV & BSA-MV & AV-MV & BSA-MV & AV-MV & BSA-MV & AV-MV & BSA-MV \\
\hline Jan & -- & -- & -- & -- & -4.119 & -23.058 & -- & -- \\
\hline Feb & -- & -- & -- & -- & 4.312 & -16.635 & - & - \\
\hline Mar & -- & -- & -- & -- & 2.353 & -15.626 & -7.475 & -14.475 \\
\hline Apr & -- & -- & -- & -- & 0.839 & -13.263 & 0.849 & -15.541 \\
\hline May & -- & -- & -- & -- & 3.708 & -12.231 & -0.309 & -16.595 \\
\hline Jun & -0.886 & -9.354 & -2.998 & -10.223 & 1.532 & -11.038 & 2.391 & -15.250 \\
\hline Jul & 1.529 & -9.840 & 3.365 & -11.724 & 1.774 & -12.017 & 5.750 & -14.738 \\
\hline Aug & 1.695 & -10.649 & -1.100 & -12.275 & 1.717 & -9.094 & -6.441 & -14.726 \\
\hline Sep & -- & -- & 1.737 & -10.689 & 0.064 & -15.710 & -9.179 & -15.190 \\
\hline Oct & -- & -- & -1.586 & -13.750 & -0.517 & -15.983 & - & - \\
\hline Nov & -- & -- & 2.533 & -18.843 & -0.939 & -22.810 & - & - \\
\hline Dec & -- & -- & -1.717 & -24.266 & 0.302 & -23.994 & - & - \\
\hline
\end{tabular}

* RE, AV, and MV represent Relative Error, Assimilated Value, and Measured Value, respectively 


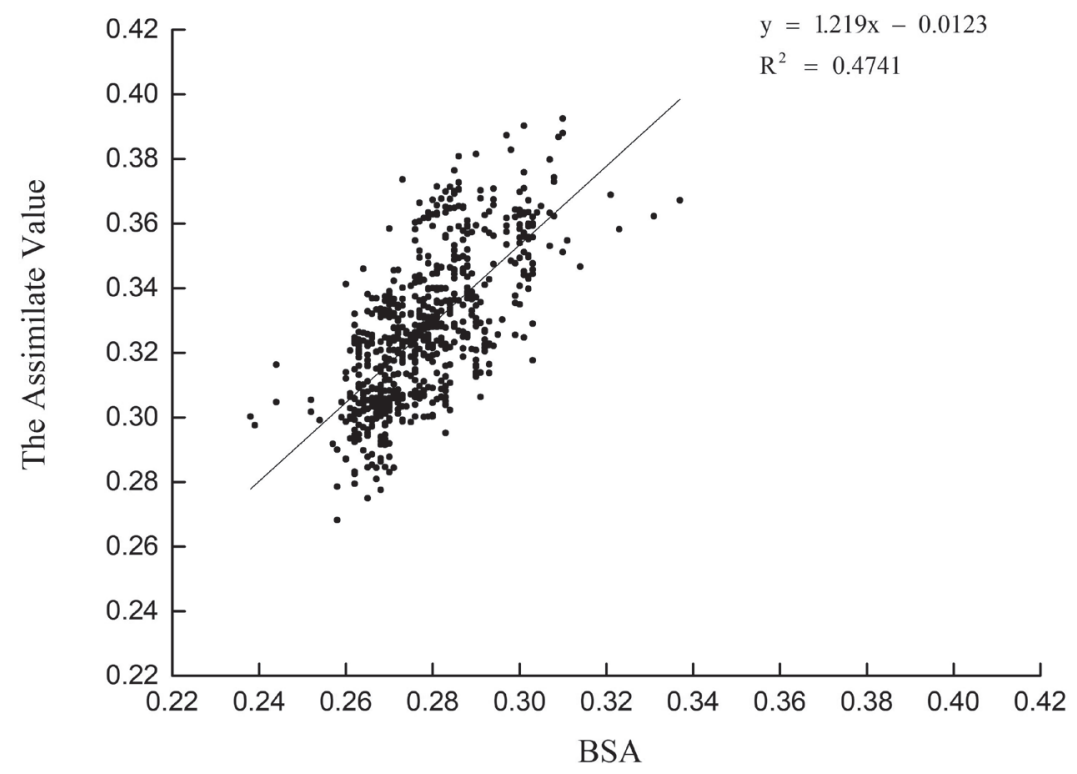

Fig. 3 Linear regression analysis between BSA and the assimilated value $(\mathrm{p}<0.01)$.

calculated using 4DVAR shows a response to continuous change in measured value over a short time, reduces the relative errors, and improves the applicability of BSA in winter.

\section{Spatial and Temporal Differences in Surface Albedo over Different Underlying Surfaces}

The daily inversion of surface albedo in 2018 was calculated using linear regression analysis between BSA and the assimilated value. The monthly surface albedo was calculated and classified (Fig. 4). The mean of surface albedo in the desert decreased gradually from January to July, reached its minimum in July (0.27), increased in August, and peaked in December (0.34). The spatial difference in monthly surface albedo was obvious, which was high in the southeast and low in the northwest. The surface albedo reached a maximum (1.00) between the Heli Mountains and Beida Mountains in January. The surface albedo showed a decreasing trend from February to July, with the main distribution range dropping from $0.25-0.40$ to $0.20-0.30$. The surface albedo from the lower reaches of the Heihe River and the east bank of the Ruoshui River to the dry basin of the Gurinai Lake in the west and the dry basin of the Guaizi Lake in the north decreased faster than that of areas near the southern Beida Mountains and southeastern Yabulai Mountains. The surface albedo and the spatial difference in surface albedo increased gradually from August to December. The surface albedo increased significantly in the lake area, areas west of the Yabulai Mountains, and south of the Guaizi Lake.

As shown in Fig. 5, the mean and median of surface albedo over different underlying surfaces reached peaked in December. The mean and median surface albedo over shifting dunes and semi-shifting dunes were lowest in July, while that of the semi-fixed and fixed dunes were lowest in August. The temporal variation in surface albedo over shifting and semishifting dunes was less than that of semi-fixed and fixed dunes, which indicated that the distribution of surface albedo over shifting and semi-shifting dunes was highly concentrated. The shifting and semishifting dunes accounted for a greater proportion of the high surface albedo values than that of the semi-fixed and fixed dunes. Compared with the skewness of the surface albedo of the semi-fixed and fixed dunes, the skewness of the surface albedo of the shifting and semishifting dunes had a positively skewed distribution which decreased over time, indicating that there was an increasing degree of bias of surface albedo over shifting and semi-shifting dunes in the low value range (Fig. 6). The skewness of different underlying surfaces reached a maximum in January, which indicated that the spatial difference of surface albedo was obvious and surface albedo tended to high value range in January. The skewness of surface albedo over fixed dunes was low obviously in March and August.

Precipitation is an important meteorological factor affecting surface albedo [38]. The surface albedo of snow-covered areas is significantly higher than that of uncovered areas in winter. In summer and autumn, precipitation is relatively high in most areas of China, and the surface vegetation coverage and soil moisture are relatively high, which results in the lowest surface albedo. However, the mechanism of the effects of vegetation coverage and soil moisture on surface albedo is controversial [39]. Compared with Fig. 4 and Fig. 8a), the surface albedo in the Badain Jaran Desert is significantly affected by precipitation. The precipitation in the Badain Jaran Desert is concentrated in July, which leads to the minimum of surface albedo over shifting dunes and semi-shifting dunes in July. 


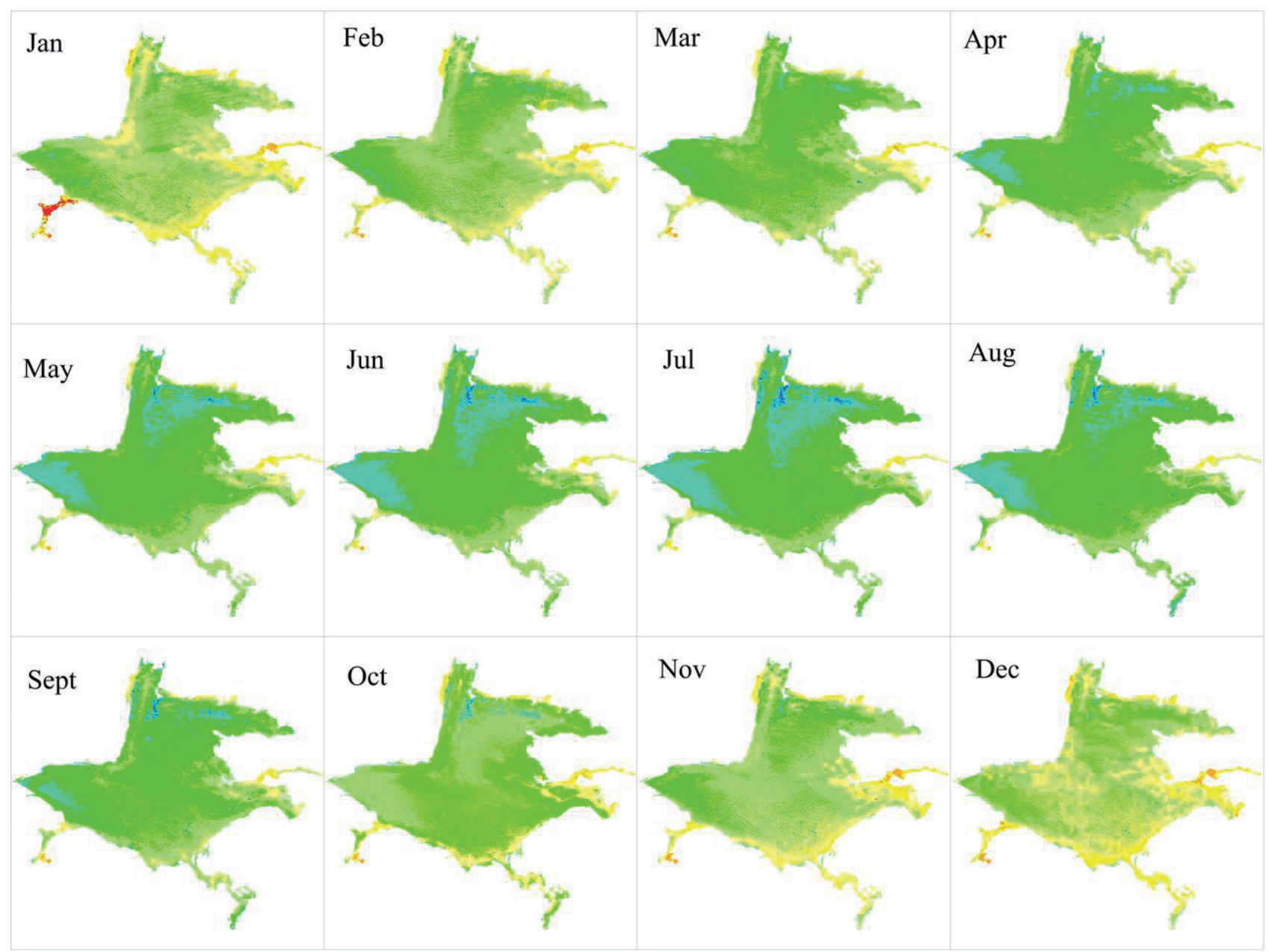

\section{Surface Albedo}

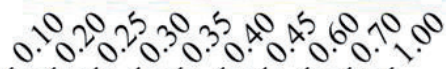

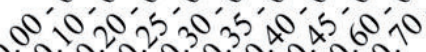

Fig. 4. Monthly variations in surface albedo in the Badain Jaran Desert.

The vegetation coverage of semi-fixed and fixed dunes is dominated by sand grass. The vegetation coverage of semi-fixed and fixed dunes is $10 \%-30 \%$ and $30 \%-50 \%$, respectively. Due to the lag effect of the vegetation in response to precipitation $[40,41]$, the surface albedo reaches a minimum in August, with maximum vegetation coverage and soil moisture. Moreover, the proportion of solar short-wave radiation absorbed by the soil is high due to the high vegetation coverage and soil moisture of fixed dunes. The bias degree of fixed dune surface albedo tending to the low value range increases. In March, the vegetation coverage of fixed dunes increases, which leads to the lower values for surface albedo over the fixed dunes. The surface roughness is a parameter that can reflect the geometric structure of the underlying surface. High surface roughness increases the reflections of solar radiation, resulting in a decrease in surface albedo [42, 43]. The roughness of semi-fixed and fixed dunes is higher than that of shifting and semishifting dunes. Thus, the low surface albedo of semi- fixed and fixed dunes accounts for a larger proportion. Shifting and semi-shifting dunes readily reflect light sources and have relatively high surface albedo values. Due to the low land surface temperature and snow cover in some high-altitude areas, surface albedo reaches a maximum in winter. The spatial difference in surface albedo between snow-covered areas and uncovered areas is significant and the bias degree of surface albedo over shifting dunes tending to the high value range increases. Dust storms frequently occur in spring and autumn, which leads to dust cover. The increase in regional aerosol concentration and thickness reduces the difference in surface albedo [44]. In summer, with an increase in precipitation, the surface albedo decreases. Precipitation also reduces the spatial difference in surface albedo over different underlying surfaces. Due to dust and precipitation, the bias degree of shifting dunes and semi-shifting dunes surface albedo tending to the high value range decreases. The distribution range of vegetation coverage of semi-fixed 


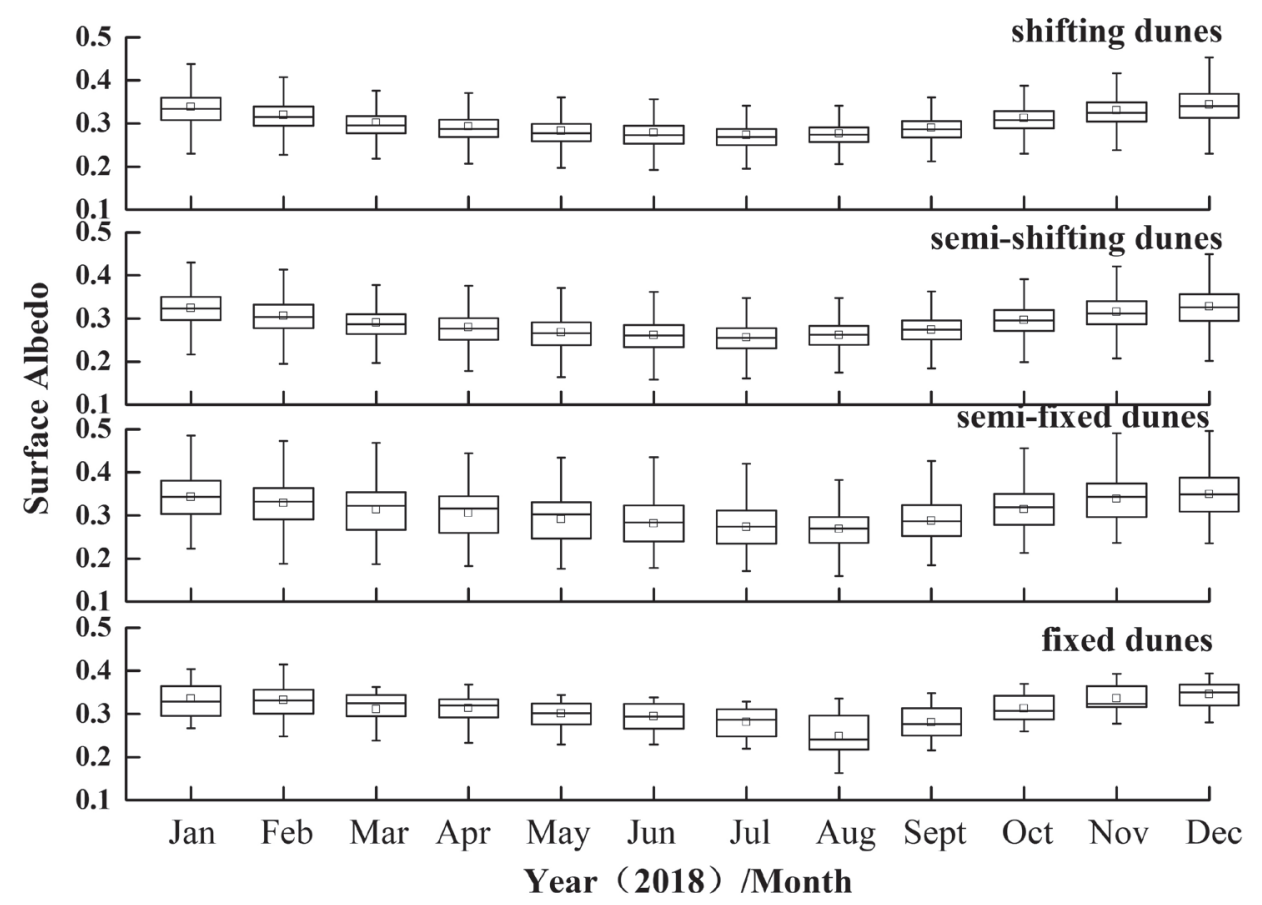

Fig. 5. Monthly median, percentiles $25 \%$ and $75 \%$ (box), and mean (square) surface albedo over different underlying surfaces in 2018.

and fixed dunes is so small that it is easy to produce mixed pixels of vegetation and bare land, which leads to a poor concentration of surface albedo range. This also explains the irregular changes in surface albedo over the semi-fixed and fixed dunes.

\section{Landscape Pattern Differences in Surface Albedo over Different Underlying Surfaces}

Table 4 showed monthly landscape metrics of surface albedo over shifting dunes, semi-shifting dunes, semi-fixed dunes, and fixed dunes. The landscape complexity of surface albedo over shifting dunes was the highest, followed by semi-shifting dunes, and fixed dunes, and landscape complexity of surface albedo over semi-fixed dunes was the lowest. The result of COHESION indicated that the spatial aggregation of patches decreased from shifting dunes to fixed dunes. Compared with shifting dunes, patches of semi-shifting dunes, semi-fixed dunes, and fixed dunes were small, and the separations were high. The results of SHDI and SIDI indicated that separation of surface albedo over

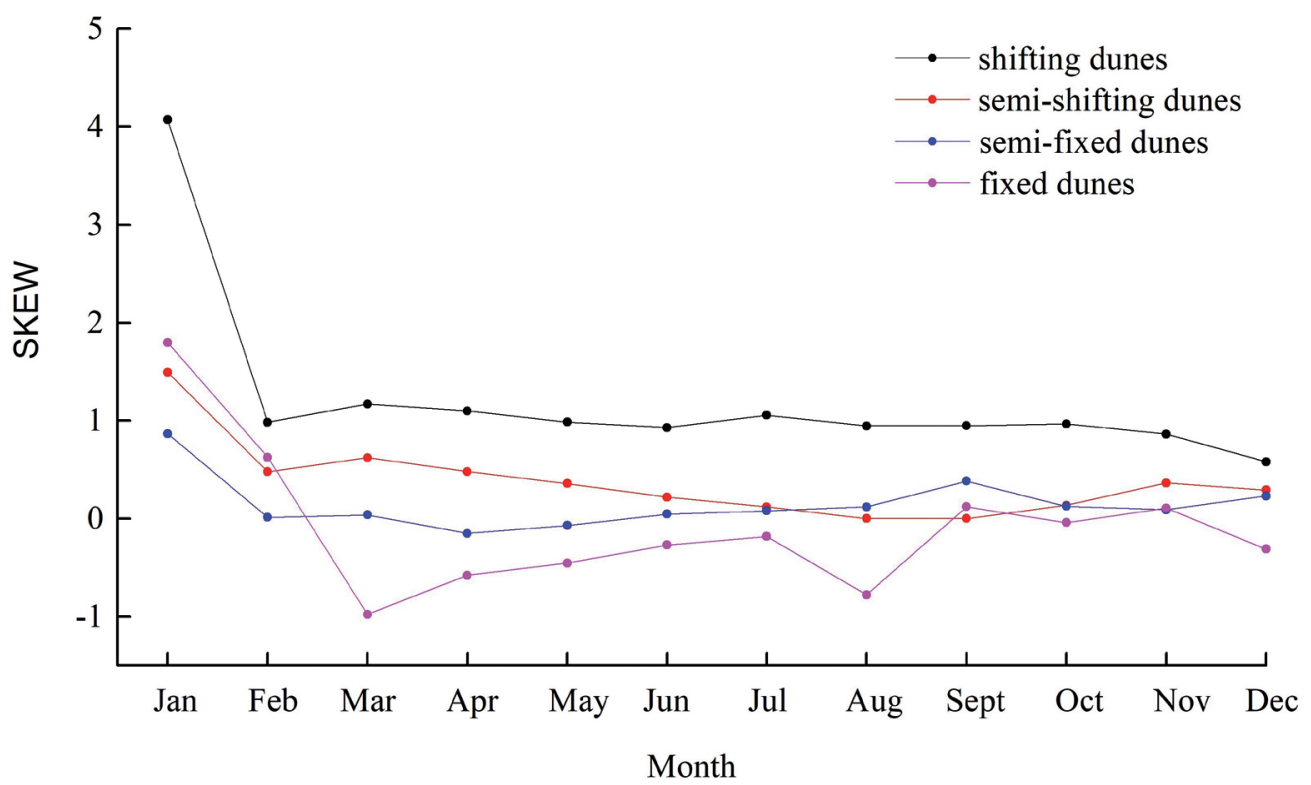

Fig. 6. Monthly skewness for shifting dunes, semi-shifting dunes, semi-fixed dunes and fixed dunes. 


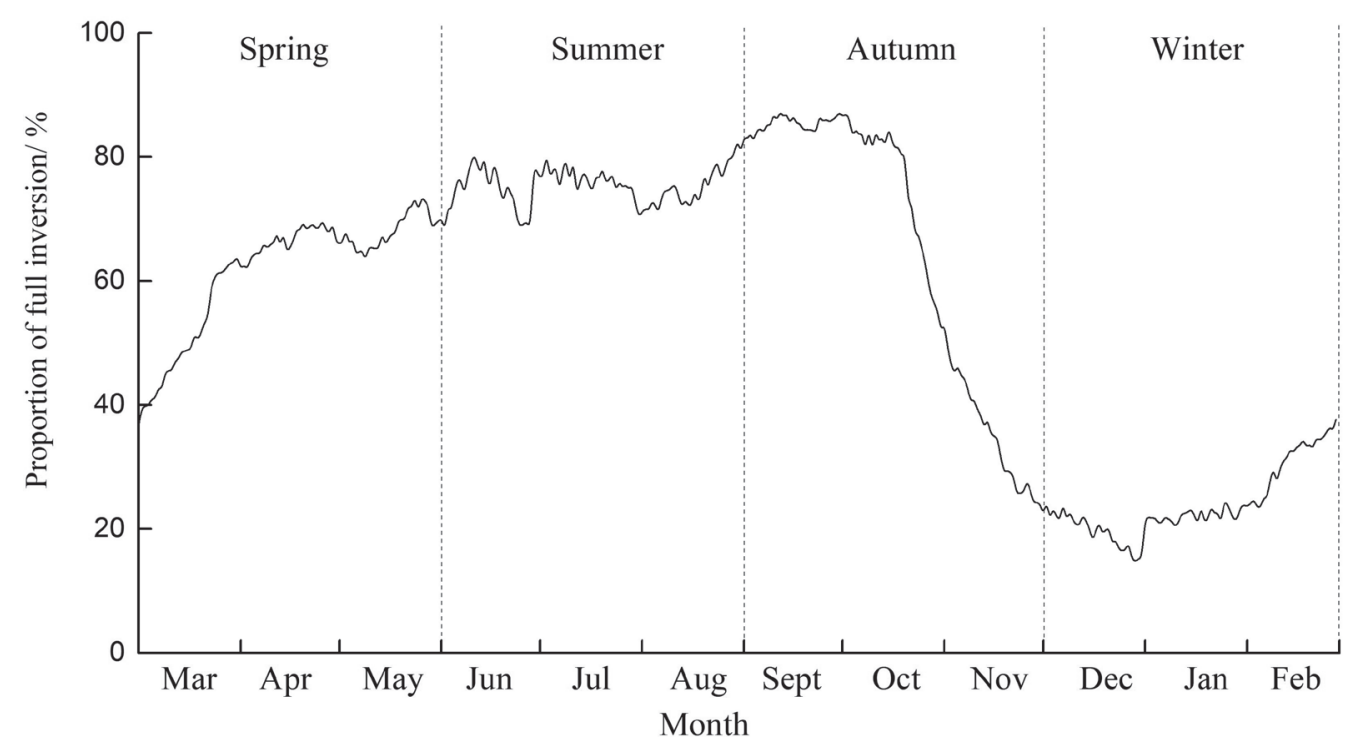

Fig. 7. Mean of proportion of the full inversion over different seasons from 2014 to 2017.

the main underlying surfaces in the Badain Jaran Desert was low and landscape dominance was strong. The landscape metrics of surface albedo over fixed dunes were unchanged in different months, which indicated that the surface albedo over fixed dunes was less affected by environmental conditions. The landscape metrics of surface albedo over the semi-fixed dunes in January and December differed to that of other months. The landscape metrics of surface albedo over the semishifting dunes in January, February, and December were significantly different. The SPLIT of surface albedo over semi-shifting dunes was significantly different in different months. The monthly difference in surface albedo PAFRAC over shifting dunes was large and the monthly difference in surface albedo SPLIT over shifting dunes was less than that of the semi-shifting dunes and semi-fixed dunes. Moreover, the difference in surface albedo SHDI and SIDI of over the shifting dunes was evident only in January and February.

Shifting dunes, semi-shifting dunes, semifixed dunes, and fixed dunes, account for $88.51 \%$, $10.28 \%, 0.84 \%$, and $0.35 \%$ of the total area of desert, respectively. The patches of shifting dunes are large and are distributed contiguously with a low degree of separation. Moreover, the form of shifting dunes is significantly affected by dust weather. Embryonic dunes (e.g. small barchan dunes, low longitudinal dunes) in the lake basin in the northwest gradually change into complex dunes (e.g. large dune chain) in the hinterland based on the predominant wind direction. The complex dunes of the hinterland gradually change into compound dunes (e.g. compound barchan dunes) in the southeast, based on the predominant wind direction [45]. Thus, the surface albedo over shifting dunes varies greatly.

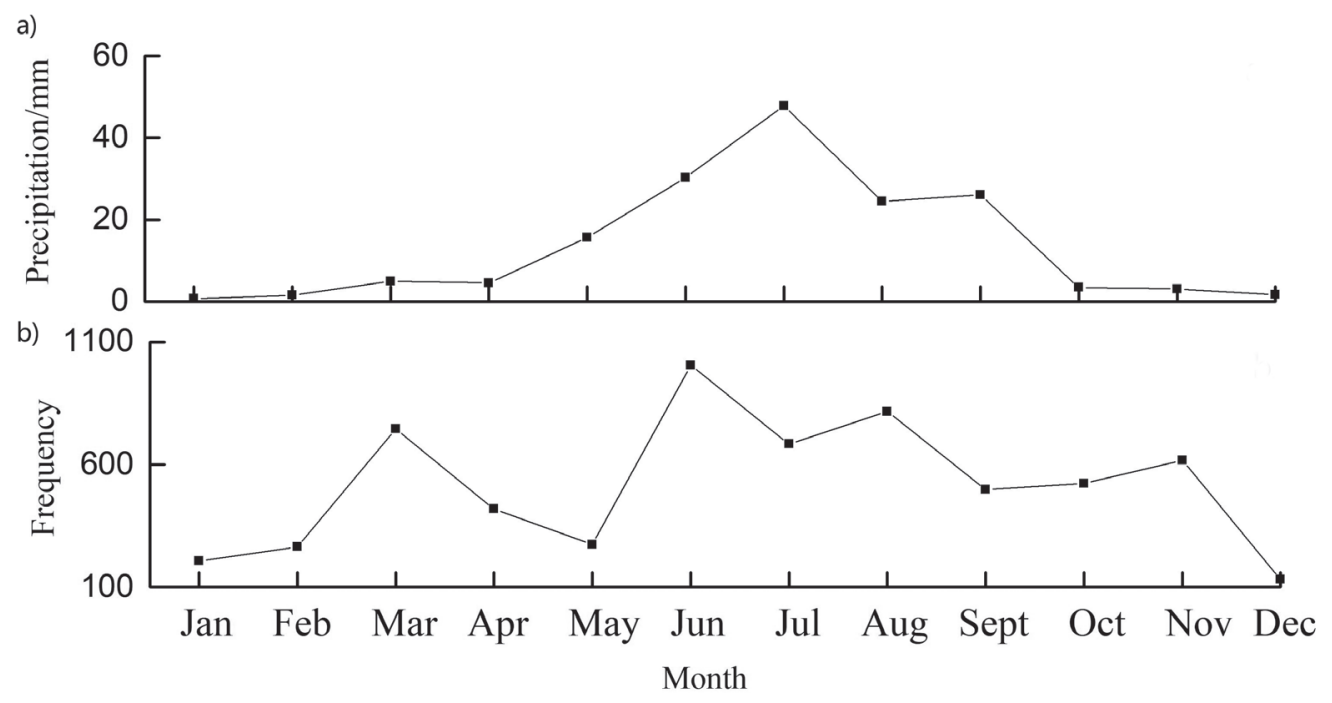

Fig. 8. Monthly precipitation variation a) and frequency of wind speed greater than $8 \mathrm{~m} \mathrm{~s} \mathrm{~b}$ ) in 2018 . 


\begin{tabular}{|c|c|c|c|c|c|c|c|c|c|c|c|c|c|c|}
\hline & & $\overrightarrow{\widehat{\theta}}$ & 8 & ఫ & $\underset{8}{8}$ & $\underset{8}{\&}$ & $\stackrel{8}{\circ}$ & \& & $\begin{array}{l}\& \\
: \\
0\end{array}$ & $\begin{array}{l}8 \\
: \\
0\end{array}$ & $\begin{array}{l}8 \\
:\end{array}$ & $\begin{array}{l}8 \\
: \\
0\end{array}$ & \begin{tabular}{l}
8 \\
\hdashline \\
0
\end{tabular} & $\stackrel{8}{8}$ \\
\hline & & $\overrightarrow{\widehat{A}}$ & $\stackrel{0}{0}$ & $\stackrel{8}{0}$ & $\begin{array}{l}8 \\
\vdots \\
0\end{array}$ & $\begin{array}{l}8 \\
\vdots \\
0\end{array}$ & $\stackrel{8}{\circ}$ & $\stackrel{0}{\circ}$ & $\stackrel{8}{\circ}$ & $\begin{array}{l}8 \\
\vdots \\
0\end{array}$ & $\begin{array}{l}8 \\
\vdots \\
0\end{array}$ & $\stackrel{8}{\circ}$ & $\stackrel{8}{\circ}$ & $\stackrel{8}{\circ}$ \\
\hline & & $\stackrel{\Xi}{\vec{\omega}}$ & $\begin{array}{l}\frac{ \pm}{n} \\
\stackrel{I}{-}\end{array}$ & $\begin{array}{l}\frac{v}{n} \\
\stackrel{-}{=}\end{array}$ & $\begin{array}{l}\vec{d} \\
\vec{n} \\
=\end{array}$ & $\begin{array}{l}\vec{d} \\
\vec{n} \\
=\end{array}$ & 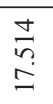 & $\begin{array}{l}\stackrel{+}{w} \\
\stackrel{n}{I}\end{array}$ & 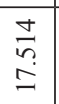 & $\begin{array}{l}\stackrel{+}{v} \\
\stackrel{n}{I}\end{array}$ & $\begin{array}{l}\stackrel{+}{v} \\
\stackrel{n}{=}\end{array}$ & $\begin{array}{l}\stackrel{ \pm}{n} \\
\end{array}$ & 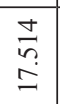 & $\begin{array}{l}\underset{⿱}{a} \\
\stackrel{n}{=}\end{array}$ \\
\hline \multirow[t]{2}{*}{ 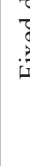 } & 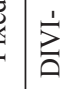 & $\begin{array}{l}\frac{z}{2} \\
\frac{1}{2} \\
\frac{1}{2}\end{array}$ & $\frac{m}{8}$ & $\frac{m}{\stackrel{O}{o}}$ & $\begin{array}{l}\text { ga } \\
\text { Oे }\end{array}$ & $\begin{array}{l}\text { ga } \\
\text { Oे }\end{array}$ & $\frac{q}{\circ}$ & $\frac{\text { ô }}{\delta}$ & $\begin{array}{l}\stackrel{q}{0} \\
\dot{O}\end{array}$ & $\begin{array}{l}q \\
\dot{\sigma} \\
\dot{O}\end{array}$ & $\begin{array}{l}\frac{P}{2} \\
\dot{O}\end{array}$ & $\begin{array}{l}q \\
\dot{\sigma} \\
o\end{array}$ & $\begin{array}{l}\tilde{\sigma} \\
\stackrel{\sigma}{o}\end{array}$ & $\frac{m}{\circ}$ \\
\hline & & 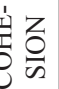 & $\begin{array}{l}\stackrel{2}{2} \\
\text { ते }\end{array}$ & $\begin{array}{l}\stackrel{2}{2} \\
\text { } \\
\text { in }\end{array}$ & 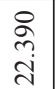 & 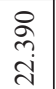 & 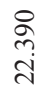 & 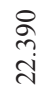 & $\begin{array}{l}\stackrel{2}{ } \\
\text { ì }\end{array}$ & $\begin{array}{l}\stackrel{2}{0} \\
\stackrel{i}{i}\end{array}$ & 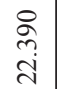 & 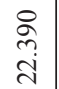 & $\begin{array}{l}\stackrel{2}{ } \\
\underset{i}{i}\end{array}$ & $\begin{array}{l}8 \\
\stackrel{\sim}{\mathrm{j}} \\
\end{array}$ \\
\hline & & 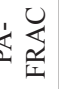 & $\stackrel{n}{n}$ & $\frac{n}{n}$ & $\stackrel{n}{n}$ & $\stackrel{n}{n}$ & $\stackrel{n}{n}$ & $\stackrel{n}{n}$ & $\stackrel{n}{n}$ & $\underset{n}{n}$ & $\underset{n}{\stackrel{n}{n}}$ & $\stackrel{n}{n}$ & $\underset{n}{n}$ & $\stackrel{n}{n}$ \\
\hline & & 官 & $\overline{8}$ & $\begin{array}{l}8 \\
\vdots \\
0\end{array}$ & $\begin{array}{l}8 \\
\stackrel{0}{0} \\
0\end{array}$ & $\begin{array}{l}8 \\
0 \\
0\end{array}$ & 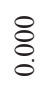 & $\stackrel{8}{\circ}$ & $\begin{array}{l}8 \\
\vdots \\
0\end{array}$ & \begin{tabular}{l}
$\stackrel{8}{0}$ \\
\hdashline \\
$\circ$
\end{tabular} & \begin{tabular}{l}
8 \\
\hdashline \\
$\circ$
\end{tabular} & $\begin{array}{l}\stackrel{0}{0} \\
:\end{array}$ & $\begin{array}{l}8 \\
\vdots \\
0\end{array}$ & $\begin{array}{l}8 \\
\vdots \\
0\end{array}$ \\
\hline & & 忢 & $\begin{array}{l}\infty \\
\stackrel{0}{0} \\
0\end{array}$ & \&̊ & $\begin{array}{l}8 \\
\vdots \\
0\end{array}$ & $\begin{array}{l}8 \\
\stackrel{0}{0} \\
0\end{array}$ & $\stackrel{8}{0}$ & \&̊ & $\begin{array}{l}0 \\
0 \\
0\end{array}$ & $\begin{array}{l}8 \\
\vdots \\
0\end{array}$ & $\begin{array}{l}8 \\
\stackrel{0}{0} \\
0\end{array}$ & $\begin{array}{l}8 \\
\vdots \\
0\end{array}$ & $\begin{array}{l}8 \\
\vdots \\
0\end{array}$ & \&̊ \\
\hline & & $\stackrel{\Xi}{\vec{\Xi}}$ & 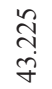 & $\begin{array}{l}\hat{E} \\
\dot{a} \\
\dot{q}\end{array}$ & $\begin{array}{l}\hat{E} \\
\dot{0} \\
\dot{q}\end{array}$ & $\begin{array}{l}\hat{E} \\
\dot{q} \\
\dot{q}\end{array}$ & $\begin{array}{l}\hat{S} \\
\dot{8} \\
\text { of }\end{array}$ & 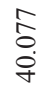 & $\begin{array}{l}\hat{E} \\
\dot{a} \\
\dot{q}\end{array}$ & $\begin{array}{l}\hat{E} \\
\dot{+} \\
\dot{q}\end{array}$ & $\begin{array}{l}\hat{E} \\
\dot{\sigma} \\
\dot{q}\end{array}$ & $\begin{array}{l}\hat{\hat{S}} \\
\dot{+} \\
\dot{q}\end{array}$ & $\begin{array}{l}\hat{E} \\
\dot{\sigma} \\
\dot{q}\end{array}$ & 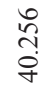 \\
\hline & & $\frac{z}{b}$ & $\begin{array}{l}\hat{a} \\
\text { à }\end{array}$ & $\begin{array}{l}n \\
\hat{o} \\
o\end{array}$ & $\begin{array}{l}n \\
\hat{a} \\
o\end{array}$ & $\begin{array}{l}n \\
\hat{\sigma} \\
o\end{array}$ & 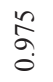 & $\begin{array}{l}n \\
\hat{o} \\
o\end{array}$ & $\begin{array}{l}n \\
\hat{a} \\
o\end{array}$ & $\begin{array}{l}n \\
\hat{a} \\
o\end{array}$ & $\begin{array}{l}n \\
\hat{a} \\
o\end{array}$ & $\begin{array}{l}n \\
\hat{a} \\
o\end{array}$ & $\begin{array}{l}n \\
\hat{a} \\
o\end{array}$ & $\begin{array}{l}n \\
\hat{o}\end{array}$ \\
\hline & & 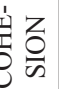 & $\begin{array}{l}n \\
0 \\
0 \\
0\end{array}$ & $\underset{\substack{\mathbb{d} \\
0}}{\vec{d}}$ & 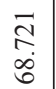 & $\underset{\substack{\vec{d} \\
\dot{0}}}{\vec{d}}$ & $\underset{\substack{\overrightarrow{0} \\
\dot{o}}}{\vec{d}}$ & $\underset{\substack{\mathbb{d} \\
0}}{\overrightarrow{\mathbb{d}}}$ & 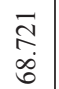 & $\begin{array}{l}\overrightarrow{\mathbb{d}} \\
\stackrel{0}{0}\end{array}$ & $\begin{array}{l}\overrightarrow{\mathbb{N}} \\
\stackrel{0}{0}\end{array}$ & $\begin{array}{l}\overrightarrow{\mathbb{d}} \\
\stackrel{\phi}{0}\end{array}$ & $\begin{array}{l}\overrightarrow{\mathbb{N}} \\
\underset{0}{0}\end{array}$ & $\begin{array}{l}\infty \\
0 \\
0 \\
0 \\
0\end{array}$ \\
\hline & & 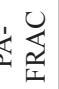 & $\stackrel{0}{\stackrel{6}{+}}$ & $\stackrel{\stackrel{\infty}{\infty}}{\stackrel{\infty}{-}}$ & $\begin{array}{c}\stackrel{O}{\infty} \\
\stackrel{\infty}{+}\end{array}$ & $\begin{array}{c}\stackrel{\infty}{+} \\
\stackrel{\infty}{-}\end{array}$ & $\stackrel{\underset{\infty}{\stackrel{\infty}{+}}}{\stackrel{-}{-}}$ & $\stackrel{\stackrel{\infty}{\stackrel{\infty}{+}}}{\stackrel{-}{-}}$ & $\begin{array}{c}\stackrel{\infty}{S} \\
\stackrel{\infty}{-}\end{array}$ & $\begin{array}{c}\stackrel{0}{\infty} \\
\stackrel{\infty}{+} \\
-\end{array}$ & $\begin{array}{c}\stackrel{\infty}{\infty} \\
\stackrel{\infty}{-}\end{array}$ & $\underset{\stackrel{\infty}{\infty}}{\stackrel{\infty}{-}}$ & $\begin{array}{c}\stackrel{O}{\infty} \\
\stackrel{\infty}{-}\end{array}$ & $\begin{array}{l}\infty \\
\stackrel{\infty}{\infty} \\
\stackrel{\infty}{-}\end{array}$ \\
\hline \multirow{6}{*}{$\frac{7}{5}$} & & $\overline{\tilde{\sigma}}$ & ชิ & \begin{tabular}{l}
8 \\
\hdashline \\
0
\end{tabular} & $\begin{array}{l}8 \\
\vdots \\
0\end{array}$ & $\begin{array}{l}8 \\
\vdots \\
0\end{array}$ & \&̊ & \&̊ & $\stackrel{8}{8}$ & $\stackrel{8}{\circ}$ & $\stackrel{8}{\circ}$ & $\stackrel{8}{8}$ & $\begin{array}{l}8 \\
\vdots \\
0\end{array}$ & 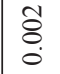 \\
\hline & & 逽 & @े & 宫 & $\begin{array}{l}0 \\
\vdots \\
0\end{array}$ & $\begin{array}{l}8 \\
\vdots \\
0\end{array}$ & ঃ̣ & \& & 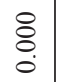 & $\begin{array}{l}\square \\
\vdots \\
0\end{array}$ & $\begin{array}{l}\square \\
\vdots \\
0\end{array}$ & 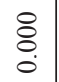 & $\begin{array}{l} \pm \\
\stackrel{0}{0} \\
0\end{array}$ & 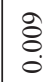 \\
\hline & & $\stackrel{\Xi}{\text { 芒 }}$ & 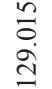 & 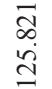 & $\begin{array}{l}\hat{b} \\
\hat{b} \\
\hat{\jmath}\end{array}$ & 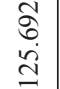 & $\begin{array}{l}2 \\
\stackrel{0}{0} \\
\ddot{d}\end{array}$ & $\begin{array}{l}\text { ठิ } \\
\text { àd }\end{array}$ & 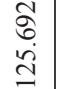 & $\begin{array}{l}\hat{d} \\
\dot{d} \\
\grave{d}\end{array}$ & $\begin{array}{l}\text { ô } \\
\text { d. } \\
\text { a }\end{array}$ & 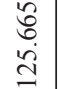 & 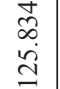 & 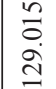 \\
\hline & & $\begin{array}{l}\frac{z}{z} \\
\frac{1}{n} \\
\frac{1}{2}\end{array}$ & ठু & ठू. & $\begin{array}{l}\hat{\sigma} \\
\text { ò }\end{array}$ & ồ & ڤ̆ & ठू. & ô & 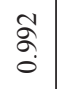 & 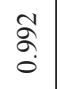 & 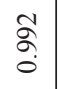 & $\begin{array}{l}\tilde{a} \\
\text { ò }\end{array}$ & 命 \\
\hline & & 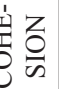 & $\begin{array}{l}0 \\
\text { ల. } \\
\stackrel{\infty}{\infty}\end{array}$ & $\begin{array}{l}\widetilde{\gamma} \\
\stackrel{\infty}{\infty}\end{array}$ & $\begin{array}{l}\hat{0} \\
\dot{q} \\
\dot{\infty}\end{array}$ & $\begin{array}{l}\hat{0} \\
\dot{q} \\
\dot{\infty}\end{array}$ & $\begin{array}{l}\infty \\
\stackrel{0}{+} \\
\stackrel{\infty}{\infty}\end{array}$ & $\begin{array}{l}\hat{o} \\
\dot{q} \\
\dot{\infty}\end{array}$ & $\begin{array}{l}\hat{q} \\
\dot{q} \\
\dot{\infty}\end{array}$ & $\begin{array}{l}\hat{q} \\
\dot{q} \\
\dot{\infty}\end{array}$ & $\begin{array}{l}\hat{q} \\
\dot{q} \\
\dot{\infty}\end{array}$ & $\begin{array}{l}\infty \\
\stackrel{0}{0} \\
\dot{\infty} \\
\dot{\infty}\end{array}$ & 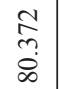 & 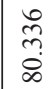 \\
\hline & & 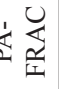 & $\stackrel{\vec{n}}{\vec{n}}$ & 귬 & $\stackrel{\vec{n}}{\vec{n}}$ & $\stackrel{\vec{n}}{\vec{r}}$ & $\stackrel{\vec{n}}{\vec{n}}$ & $\stackrel{\vec{n}}{\vec{n}}$ & $\stackrel{\vec{n}}{\vec{n}}$ & $\stackrel{\overrightarrow{\vec{n}}}{\overrightarrow{-}}$ & $\stackrel{\overrightarrow{\vec{r}}}{\overrightarrow{-}}$ & $\stackrel{\vec{n}}{\vec{n}}$ & 帘 & $\stackrel{\stackrel{a}{n}}{\vec{n}}$ \\
\hline \multirow{6}{*}{ 青 } & & $\overrightarrow{\mathrm{\theta}}$ & $\stackrel{0}{\varrho}$ & 8 & $\begin{array}{l}8 \\
\vdots \\
0\end{array}$ & $\begin{array}{l}8 \\
\vdots \\
0\end{array}$ & $\stackrel{8}{\circ}$ & \&̊ & $\begin{array}{l}\stackrel{8}{0} \\
\stackrel{0}{0}\end{array}$ & $\begin{array}{l}\stackrel{8}{0} \\
\stackrel{0}{0}\end{array}$ & $\begin{array}{l}8 \\
\vdots \\
0\end{array}$ & $\begin{array}{l}8 \\
\vdots \\
0\end{array}$ & $\begin{array}{l}8 \\
\vdots \\
0\end{array}$ & 嗃 \\
\hline & & 逽 & \& & $\overline{8}$ & $\begin{array}{l}8 \\
8 \\
0 \\
0\end{array}$ & $\begin{array}{l}8 \\
0 \\
0\end{array}$ & $\stackrel{\circ}{\circ}$ & $\stackrel{8}{\circ}$ & $\begin{array}{l}\stackrel{0}{0} \\
\stackrel{0}{0}\end{array}$ & $\begin{array}{l}8 \\
0 \\
0\end{array}$ & $\begin{array}{l}8 \\
0 \\
0\end{array}$ & $\begin{array}{l}8 \\
0 \\
0\end{array}$ & $\begin{array}{l}8 \\
0 \\
0\end{array}$ & 音 \\
\hline & & $\stackrel{\Xi}{: ~}$ & d & $\tilde{\varepsilon}$ & $\stackrel{\tilde{\delta}}{-}$ & $\stackrel{\tilde{\delta}}{-}$ & $\stackrel{\tilde{o}}{-}$ & $\stackrel{\check{\delta}}{.}$ & 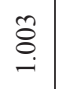 & 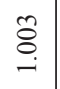 & 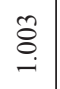 & $\stackrel{\check{\delta}}{-}$ & $\underset{\dot{\delta}}{\tilde{\delta}}$ & $\stackrel{\circ}{\circ}$ \\
\hline & & 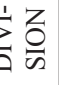 & 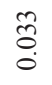 & $\stackrel{\wp}{0}$ & $\begin{array}{l}\tilde{o} \\
\dot{0} \\
0\end{array}$ & $\begin{array}{l}0 \\
0 \\
0\end{array}$ & $\stackrel{0}{0}$ & \%̊. & $\underset{0}{0}$ & $\begin{array}{l}m \\
0 \\
0\end{array}$ & $\begin{array}{l}0 \\
\stackrel{0}{0}\end{array}$ & 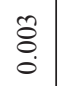 & $\begin{array}{l}0 \\
\stackrel{0}{0}\end{array}$ & $\begin{array}{l}0 \\
0 \\
0\end{array}$ \\
\hline & & $\begin{array}{l}1 \\
\frac{1}{1} \\
z\end{array}$ & $\bar{\alpha}$ & $\begin{array}{l}\hat{\alpha} \\
\hat{\alpha}\end{array}$ & $\begin{array}{l}\infty \\
\stackrel{\alpha}{\alpha} \\
\alpha\end{array}$ & $\begin{array}{l}\infty \\
\circ \\
\alpha\end{array}$ & $\begin{array}{l}\infty \\
\stackrel{\alpha}{\alpha} \\
\alpha\end{array}$ & $\begin{array}{l}\infty \\
\stackrel{\alpha}{\alpha} \\
\alpha\end{array}$ & $\begin{array}{l}\infty \\
\text { oे } \\
\text { aे }\end{array}$ & $\begin{array}{l}\infty \\
\stackrel{\alpha}{\alpha} \\
\sigma\end{array}$ & $\begin{array}{l}\infty \\
\text { òे } \\
\alpha\end{array}$ & $\begin{array}{l}\infty \\
\stackrel{\alpha}{\alpha} \\
\alpha\end{array}$ & 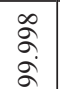 & $\begin{array}{l}\infty \\
\alpha \\
\alpha \\
\alpha\end{array}$ \\
\hline & & $\mathbb{2}$ & 午 & $\hat{\sim}$ & 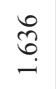 & $\stackrel{n}{n}$ & $\stackrel{\text { f }}{n}$ & $\stackrel{\hat{n}}{n}$ & $\stackrel{\hat{n}}{n}$ & $\stackrel{\tilde{n}}{\sim}$ & $\stackrel{\tilde{n}}{\stackrel{n}{-}}$ & $\begin{array}{l}\stackrel{0}{n} \\
\stackrel{n}{n}\end{array}$ & $\underset{n}{\tilde{n}}$ & $n$ \\
\hline & & & s & & $\sum_{\Sigma}^{\tilde{\pi}}$ & 殅 & $\stackrel{\vec{m}}{\lambda^{m}}$ & 忍 & $\Xi$ & $\stackrel{\infty 0}{\vec{\psi}}$ & $\begin{array}{l}\stackrel{े}{c} \\
\ddot{n}\end{array}$ & $\overrightarrow{\check{o}}$ & $\vec{z}$ & $\ddot{\mathscr{U}}$ \\
\hline
\end{tabular}


Semi-shifting dunes are crisscrossed with shifting dunes in the hinterland of the Badain Jaran Desert and are distributed contiguously at the edge of the desert. The complexity of surface albedo over semi-shifting dunes is lower than that of shifting dunes. Semi-fixed dunes intersperse semi-shifting dunes at the edge of the desert and the complexity is the lowest. Mega-dunes are found widely across the hinterland of the Badain Jaran Desert and the difference between dunes and interdunes is significant. The number of dunes gradually decreases and the distance between dunes increases from the hinterland of the desert to the edge, which leads to a decrease in landscape dominance of surface albedo at the edge of the desert. Semi-fixed dunes and fixed dunes are mainly found at the edge of desert, and landscape dominance is poor. In winter, the northwest wind prevails, and strong winds occur in the southeast desert, where semi-shifting dunes and semi-fixed dunes are distributed contiguously. Thus, landscape metrics of semi-shifting and semi-fixed dunes are significantly different from other seasons. In spring and autumn, the monthly surface albedo PAFRAC varies significantly over the shifting dunes due to dust with low organic matter content [46]. The content of the sand particles is low and there are strong soil cohesiveness and stability in the structure of the fixed dunes [47]. Thus, there is no difference in the monthly surface albedo landscape metrics over the fixed dunes.

This paper provides a new idea for the spatial and temporal fusion of remote sensing image data. However, it only focuses on one meteorological station. It is necessary to add more measured surface albedo from different meteorological stations inside the Badain Jaran Desert to verify accuracy of assimilation on regional scale. In order to obtain more accurate results of assimilation, improving the algorithm and using high-resolution data are necessary.

\section{Conclusions}

The average relative error decreased by $12.271 \%$ when surface albedo based on OLI is assimilated into BSA with 4DVAR. It can improve poor applicability of BSA in winter and adjust BSA to better respond to the changes in the measured value over a short time range.

Surface albedo is affected by precipitation in Badain Jaran Desert, which is highest in winter, followed by spring and autumn, and the lowest in summer. The response of vegetation to precipitation exhibits a lag effect, which delays the occurrence of minimum surface albedo over the semi-fixed and fixed dunes.

Due to variations in the roughness of the underlying surfaces, the high value of surface albedo over shifting and semi-shifting dunes is greater than that of semifixed dunes and fixed dunes.

The difference in organic matter and sand content over different underlying surfaces is significant, which leads to a significant difference in the monthly surface albedo PAFRAC over the shifting dunes and no difference in the monthly surface albedo landscape metrics over the fixed dunes.

\section{Acknowledgements}

This research was financially supported by the National Natural Science Foundation of China (Grant No. 41975010 and 41888101), Desert Meteorological Science Research Foundation of China (Grant No. Sqj2020011), Fundation of Shanxi Agricultural University (Grant No. 2016YJ16 and 2017022), and the Tianshan Youth Talents Plan Project of Xinjiang (2019Q038). We would like to thank Mrs. Huifei Han for English language proofreading.

\section{Conflict of Interest}

The authors declare that they have no conflicts of interest.

\section{References}

1. FACCHINI M.C., MIRCEA M., FUZZI S., CHARLSON R.J. Cloud albedo enhancement by surface-active organic solutes in growing droplets. Nature, 401 (6750), 257, 1999.

2. RYKEN A., BEARUP L.A., JEFFERSON J.L., CONSTANTINE P., MAXWELL R.M. Sensitivity and model reduction of simulated snow processes: Contrasting observational and parameter uncertainty to improve prediction. Advances in Water Resources, 135, 1, 2020.

3. CHARNEY J., QUIRK W.J., CHOW S.H., KORNFIELD J. A Comparative Study of the Effects of Albedo Change on Drought in Semi-Arid Regions. Journal of the Atmospheric Sciences, 34 (9), 1366, 1977.

4. YANG F., HUANG J.P., ZHOU C.L., YANG X.H., ALI M., LI C.F., PAN H.L, HUO W., YU H.P., LIU X.Y., ZHENG X.Q., HAN D.L., HE Q., MENG L., CHANG J. Taklimakan desert carbon-sink decreases under climate change. Science Bulletin, 65 (6), 431, 2020.

5. YANG F., HUANG J.P., HE Q., ZHENG X.Q., ZHOU C.L., PAN H.L., HUO W., YU H.P., LIU X.Y., MENG L., HAN D.L., ALI M., YANG X.H. Impact of differences in soil temperature on the desert carbon sink. Geoderma, 379, 1, 2020.

6. YANG F., YANG X., HUO W., ALI M., ZHENG X.Q., ZHOU C.L., HE Q. A continuously weighing, high frequency sand trap: Wind tunnel and field evaluations. Geomorphology, 293, 84, 2017.

7. BAI Y., WANG N.A., LIAO K.T., KLENK P. Geomorphological evolution revealed by aeolian sedimentary structure in Badain Jaran Desert on Alxa Plateau, Northwest China. Chinese Geographical Science, 21 (3), 267, 2011.

8. MA Y.D., ZHAO J.B., SHAO T.J., JIA Z.F., ZHAO Z.Q., GUAN Z.L. Hydrological Cycle and Lake Water Source Indicated by Microrelief-Evaporite-Vegetation-Runoff Assemblage of Badain Jaran Desert. Water, 11 (7), 1, 2019.

9. FAN X.L., ZHANG X.Y., TIAN M.Z. Climate change during the last glacial period on the southeast margin 
of Badain Jaran Desert, Northwest China. Journal of Mountain Science, 16 (10), 2379, 2019.

10. HU W.F., WANG N.A., ZHAO L.Q., NING K., ZHANG X.H., SUN J. Surface energy and water vapor fluxes observed on a megadune in the Badain Jaran Desert, China. Journal of Arid Land, 7 (5), 579, 2015.

11. CLAESSEN J., MOLINI A., MARTENS B., DETTO M., DEMUZERE M., MIRALLES D.G. Global biosphereclimate interaction: a causal appraisal of observations and models over multiple temporal scales. Biogeosciences, 16 (24), 4851, 2019.

12. DONG N., LIU Z., LUO M., FANG C.Y., LIN H. The Effects of Anthropogenic Land Use Changes on Climate in China Driven by Global Socioeconomic and Emission Scenarios. Earths Future, 7 (7), 784, 2019.

13. KUANG W.H., LIU A.L., DOU Y.Y., LI G.Y., LU D.S. Examining the impacts of urbanization on surface radiation using Landsat imagery. Giscience \& Remote Sensing, 56 (3), 462, 2019.

14. WAGGONER D.G., SOKOLIK I.N. Seasonal dynamics and regional features of MODIS-derived land surface characteristics in dust source regions of East Asia. Remote Sensing of Environment, 114 (10), 2126, 2010.

15. KARNIELI A., QIN Z.H., WU B., PANOV N., YAN F. Spatio-Temporal Dynamics of Land-Use and Land-Cover in the Mu Us Sandy Land, China, Using the Change Vector Analysis Technique. Remote Sensing, 6 (10), 9316, 2014.

16. LIU F.S., CHEN Y., LU H.Y., SHAO H.B. Albedo indicating land degradation around the Badain Jaran Desert for better land resources utilization. Science of the Total Environment, 578, 67, 2017.

17. CSISZAR I., GUTMAN G. Mapping global land surface albedo from NOAA AVHRR. Journal of Geophysical Research Atmospheres, 104 (D6), 6215, 1999.

18. WANG Z.S., SCHAAF C.B., SUN Q.S., KIM J., ERB A.M., GAO F., ROMAN M.O., YANG Y., PETROY S., TAYLOR J.R., MASEK J.G., MORISETTE J.T., ZHANG X.Y., PAPUGA S.A. Monitoring land surface albedo and vegetation dynamics using high spatial and temporal resolution synthetic time series from Landsat and the MODIS BRDF/NBAR/albedo product. International Journal of Applied Earth Observation and Geoinformation, 59, 104, 2017.

19. LIMBACHER J.A., KAHN R.A. MISR researchaerosol-algorithm refinements for dark water retrievals. Atmospheric Measurement Techniques, 7 (11), 3989, 2014.

20. GAO F., HE T., MASEK J.G., SHUAI Y.M., SCHAAF C.B. Angular effects and correction for medium resolution sensors to support crop monitoring. IEEE J Sel Top Appl Earth Obs Remote Sens, 7 (11), 4480, 2014.

21. SHUAI Y.M., MASEK J.G., GAO F., SCHAAF C.B. An algorithm for the retrieval of $30-\mathrm{m}$ snow-free albedo from Landsat surface reflectance and MODIS BRDF. Remote Sens Environ, 115 (9), 2204, 2011.

22. HE T., LIANG S.L., WANG D.D., CAO Y.F., GAO F., YU Y.Y., FENG M. Evaluating land surface albedo estimation from Landsat MSS, TM, ETM+, and OLI data based on the unified direct estimation approach. Remote Sensing of Environment, 204, 181, 2018.

23. LI Q., SUN R., LIU Q., YU T., LIU Q.R., ZHU A.R. The Spatial-temporal Variation of Land Surface Albedo in Hengshui During 2001-2015 by Blending Landsat and GLASS Data. Int J Earth Environ Sci, 4, 167, 2019.

24. MENG J.H., DU X., WU B.F. Generation of high spatial and temporal resolution NDVI and its application in crop biomass estimation. International Journal of Digital Earth, 6 (3), 203, 2013.

25. YU T., SUN R., XIAO Z.Q., ZHANG Q., WANG J.M., LIU G. Generation of High Resolution Vegetation Productivity from a Downscaling Method. Remote Sens, 10 (11), 1, 2018

26. XIE Y., WANG P.X., BAI X.J., KHAN J., ZHANG S.Y., LI L., WANG L. Assimilation of the leaf area index and vegetation temperature condition index for winter wheat yield estimation using Landsat imagery and the CERESWheat model. Agricultural and Forest Meteorology, 246, 194, 2017

27. DONG Z.B., WANG T., WANG X.M. Geomorphology of the megadunes in the Badain Jaran desert. Geomorphology, 60 (1-2), 191, 2004.

28. CHEN A.J., LIU Y.J., BIAN L.G., ZHU X.X., WANG F. Analysis of the differences between the two kinds of MODIS albedos over China. Acta Meteorologica Sinica, 70 (5), 1119, 2012.

29. SHA Z.Y., ZHONG J.L., BAI Y.F., TAN X.C., LI J. Spatiotemporal patterns of satellite-derived grassland vegetation phenology from 1998 to 2012 in Inner Mongolia, China. Journal of Arid Land, 8 (3), 462, 2016.

30. LIANG S.L. Narrowband to broadband conversions of land surface albedo I algorithms. Remote Sensing of Environment, 76 (2), 213, 2001.

31. LIANG S.L, SHUEY C.J., RUSS A.L., FANG H.L., CHEN M.Z., WALTHALL C.L., DAUGHTRY S.T., JR R.H. Narrowband to broadband conversions of land surface albedo: II. Validation. Remote Sensing of Environment, 84 (1), 25, 2003

32. KABIR S.F., ASSUMANING G.A., CHANG S.Y. Efficiency of using 4DVar, 3DVar and EnKF data assimilation methods in groundwater contaminant transport modelling. European Journal of Environmental and Civil Engineering, 23 (4), 515, 2019.

33. FUJIMOTO W., WASEDA T. Ensemble-Based Variational Method for Nonlinear Inversion of Surface Gravity Waves. Journal of Atmospheric and Oceanic Technology, 37 (1), 17, 2020.

34. MEARS M., BRINDLEY P., JORGENSEN A., ERSOY E., MAHESWARAN R. Greenspace spatial characteristics and human health in an urban environment: An epidemiological study using landscape metrics in Sheffield, UK. Ecological Indicators, 106, 1, 2019.

35. MILLAN-AGUILAR O., NETTEL-HERNANZ A., HURTADO-OLIVA M.A., DODD R.S., FLORESCARDENAS F., MANZANO-SARABIA M. Landscape Metrics and Conservation Status of Five Mangrove Wetlands in the Eastern Gulf of California Margin. Journal of Coastal Research, 36 (1), 94, 2020.

36. TIAN X.P., LIU Q., SONG Z.W., DOU B.C., LI X.H. Aerosol Optical Depth Retrieval From Landsat 8 OLI Images Over Urban Areas Supported by MODIS BRDF/ Albedo Data. Ieee Geoscience and Remote Sensing Letters, 15 (7), 976, 2018.

37. ZHOU Y., WANG D.D., LIANG S.L., YU Y.Y., HE T. Assessment of the Suomi NPP VIIRS Land Surface Albedo Data Using Station Measurements and HighResolution Albedo Maps. Remote Sensing, 8 (2), 137, 2016.

38. LI J.G., ALI M., LI Z.G., JIANG C.L., WANG M.Z. Effects of Summer Rainfall on the Soil Thermal Properties and Surface Energy Balances in the Badain Jaran Desert. Advances in Meteorology, 2019, 1, 2019.

39. LI Z.C., YANG J.X., GAO X.Q., ZHENG Z.Y., YU Y., HOU X.H., WEI Z.Z. Impact of soil moisture and winter 
wheat height from the Loess Plateau in Northwest China on surface spectral albedo. Theoretical and Applied Climatology, 131 (3-4), 857, 2018.

40. CAO X.M., CHEN X., BAO A. Response of vegetation to temperature and precipitation in Xinjiang during the period of 1998-2009. Journal of Arid Land, 3 (2), 94, 2011.

41. LIU C., ZHAO W.Z., LIU B, MENG Y.Y. Distribution Characteristics and Dynamic Changes of Vegetation in Badain Jaran Desert: Based on UAV and MODIS Data. Journal of Desert Research, 39 (4), 92, 2019.

42. CIERNIEWSKI J., CEGLAREK J., KARNIELI A., KROLEWICZ S., KAZMIEROWSKI C., ZAGAJEWSKI B. Predicting the diurnal blue-sky albedo of soils using their laboratory reflectance spectra and roughness indices. Journal of Quantitative Spectroscopy \& Radiative Transfer, 200, 25, 2017.

43. LABARRE S., JACQUEMOUD S., FERRARI C., DELORME A., DERRIEN A., GRANDIN R., JALLUDIN M., LEMAITRE F., METOIS M., PIERROTDESEILLIGNY M., RUPNIK E., TANGUY B. Retrieving soil surface roughness with the Hapke photometric model:
Confrontation with the ground truth. Remote Sensing of Environment, 225, 1, 2019.

44. YANG B., BRÄUNING A., ZHANG Z.Y., DONG Z.B., ESPER J. Dust storm frequency and its relation to climate changes in Northern China during the past 1000 years. Atmospheric Environment, 41 (40), 9288, 2007.

45. ZHANG X., LIU P.P., PAN B.L., WEI M.J., ZHANG Z.Y. Tracing the dune activation of Badain Jaran Desert and Tengger Desert by using near infrared spectroscopy and chemometrics. Journal of near Infrared Spectroscopy, 27 (5), 370, 2019.

46. GAO Y., DANG P., ZHAO Q.X., LIU J.L., LIU J.B. Effects of vegetation rehabilitation on soil organic and inorganic carbon stocks in the Mu Us Desert, northwest China. Land Degradation \& Development, 29 (4), 1031, 2018.

47. YANG R., DU Z.Y., KONG J.Q., SU Y.Z., XIAO X.M., LIU T.N., WANG M., FAN G.P. Patterns of soil nitrogen mineralization under a land-use change from desert to farmland. European Journal of Soil Science, 71 (1), 60, 2020. 